Subscriber access provided by Caltech Library

\title{
Article
}

\section{Probing Binding Interactions of Cytisine Derivatives to the \#4\#2 Nicotinic Acetylcholine Receptor}

Annet E.M. Blom, Hugo Rego Campello, Henry A Lester, Timothy Gallagher, and Dennis A. Dougherty J. Am. Chem. Soc., Just Accepted Manuscript • DOI: 10.1021/jacs.9b06580 • Publication Date (Web): 13 Sep 2019

Downloaded from pubs.acs.org on September 16, 2019

\section{Just Accepted}

"Just Accepted" manuscripts have been peer-reviewed and accepted for publication. They are posted online prior to technical editing, formatting for publication and author proofing. The American Chemical Society provides "Just Accepted" as a service to the research community to expedite the dissemination of scientific material as soon as possible after acceptance. "Just Accepted" manuscripts appear in full in PDF format accompanied by an HTML abstract. "Just Accepted" manuscripts have been fully peer reviewed, but should not be considered the official version of record. They are citable by the Digital Object Identifier (DOI®). "Just Accepted" is an optional service offered to authors. Therefore, the "Just Accepted" Web site may not include all articles that will be published in the journal. After a manuscript is technically edited and formatted, it will be removed from the "Just Accepted" Web site and published as an ASAP article. Note that technical editing may introduce minor changes to the manuscript text and/or graphics which could affect content, and all legal disclaimers and ethical guidelines that apply to the journal pertain. ACS cannot be held responsible for errors or consequences arising from the use of information contained in these "Just Accepted" manuscripts. 


\section{INTRODUCTION}

Nicotinic acetylcholine receptors (nAChRs) have been studied for their role in synaptic transmission and consequently their involvement in neural disorders such as nicotine addiction, epilepsy, and Parkinson's disease. ${ }^{1,2}$ Tobacco use causes more than 7 million deaths per year worldwide, and smoking is the leading cause of preventable death. ${ }^{3}$ In addition, smoking costs the United States nearly $\$ 170$ billion in direct medical care for adults each year. ${ }^{4,5}$ Nicotine's behavioral effects result from its interaction with nAChRs. ${ }^{6}$ Various studies have linked polymorphisms in $\mathrm{nAChR}$ genes to risk of tobacco and alcohol dependence and have established that nicotine functions as an intracellular chaperone of nAChRs. ${ }^{7}$ However, developing new treatments for these targets remains challenging, as the various subtypes of nAChRs are structurally similar, and the mechanism of receptor activation, and how this may or may not vary with subtype, is still not completely understood.

$\mathrm{nAChRs}$ are pentameric ligand-gated ion channels and part of the Cys-loop receptor family. Neuronal nAChRs are composed of five subunits, forming heteromers of $\alpha 2-\alpha 11$ and $\beta 2$ $\beta 4$, or $\alpha$-only homomers. ${ }^{8,9}$ Various combinations of subunits and stoichiometries exist, but the most abundant in the brain is the $\alpha 4 \beta 2 \mathrm{nAChR}$, the high affinity nicotine receptor, assembling into both $(\alpha 4)_{2}(\beta 2)_{3}$ and $(\alpha 4)_{3}(\beta 2)_{2}$ stoichiometries (for simplicity, we refer to these as $\mathrm{A} 2 \mathrm{~B} 3$ and $\mathrm{A} 3 \mathrm{~B} 2$, respectively). ${ }^{10,11}$ Both stoichiometries are functional and have distinct biophysical properties. Changes in subunit stoichiometry are linked to both nicotine addiction and autosomal dominant nocturnal frontal lobe epilepsy. ${ }^{7,12-14}$ Therefore, there is strong motivation for gaining a better understanding of differential agonist effects on these two stoichiometries of the $\alpha 4 \beta 2 \mathrm{nAChR}$.

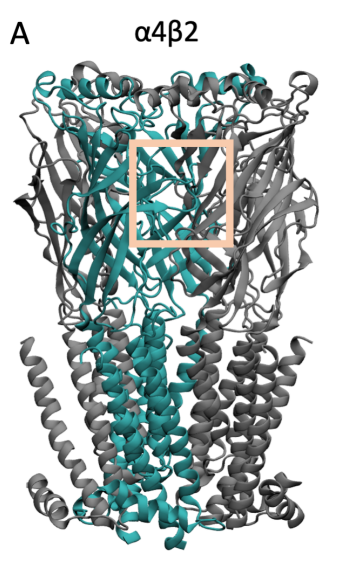

B

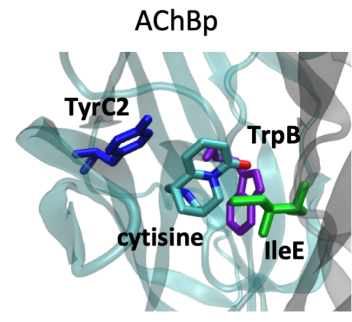

C

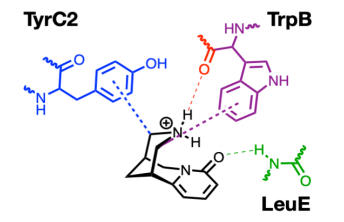

Figure 1. Agonist binding site at the $\alpha 4 \beta 2 \mathrm{nAChR}$. (A) Side view of the crystal structure of human $\alpha 4 \beta 2$ receptor nAChR (PDB ID: $5 \mathrm{KXI}), \alpha 4$ subunit in teal, $\beta 2$ subunit in grey. The agonist binding site at the $\alpha 4 / \beta 2$-interface is indicated with a square. (B) Closer look at the binding pocket. Crystal structure shown here is AChBP with cytisine bound (PDB ID: 4BQT). Functionally relevant residues probed in this study are highlighted: $\operatorname{TrpB}$ (purple), LeuE (green) (Ile in AChBP), TyrC2 (blue). (C) Schematic view of ligand-binding interactions of cytisine; cation- $\pi$ interactions in purple and blue, hydrogen bonds in green and red.

Previous studies have established a binding model for nicotine and other agonists to several nAChR subtypes (Figure 1). ${ }^{15-}$ ${ }^{17}$ For the $\alpha 4 \beta 2$ subtype three key binding interactions were identified: a cation- $\pi$ interaction to W154 (TrpB, so named because it is on loop B of six discontinuous regions, A through F, of the receptor that contribute to the agonist binding site), a 
hydrogen bond to the backbone carbonyl of $\operatorname{TrpB}$, and a hydrogen bond to the backbone NH L119 in Loop E (LeuE) of the complementary subunit. It has been shown that the cation- $\pi$ interaction is occasionally formed to a different aromatic residue of the five in the binding pocket; such is the case for acetylcholine and epibatidine in the $\alpha 7$ receptor, where this interaction is to TyrA instead of the more common TrpB ${ }^{18}$ Not all agonists can make both hydrogen bonds. For example, as would be expected for a quaternary ammonium ion, acetylcholine does not make the hydrogen bond to the backbone carbonyl of TrpB. ${ }^{15}$

In addition to these structure-function studies, drug discovery efforts targeting nAChRs have produced many compounds with differential potencies and efficacies. The partial agonist (-)-cytisine, marketed as Tabex ${ }^{\circledR}$, has been available in Eastern Europe for smoking cessation for many years. ${ }^{19-26}$ Various cytisine derivatives have been developed, including functionalization at the piperidine ring, ${ }^{27-32}$ and at the pyridone ring. ${ }^{33-37}$ In addition, cytisine played a role in the development of varenicline, ${ }^{38}$ marketed as Chantix ${ }^{\circledR}$ for smoking cessation. Cytisine also shows a novel subtype selectivity, in that it is a partial agonist for the $\mathrm{A} 3 \mathrm{~B} 2 \mathrm{nAChR}$, but does not significantly activate $\mathrm{A} 2 \mathrm{~B} 3$, where it is effectively a competitive antagonist. Interestingly, the three binding interactions exhibit distinct binding strengths for cytisine in the two stoichiometries of $\alpha 4 \beta 2 .^{39}$ The cation- $\pi$ interaction to $\operatorname{TrpB}$ is comparable in both $\mathrm{A} 2 \mathrm{~B} 3$ and $\mathrm{A} 3 \mathrm{~B} 2$, but the hydrogen bonds appear to have differential strengths; in A2B3 the hydrogen bond to LeuE is stronger, whereas in $\mathrm{A} 3 \mathrm{~B} 2$ the hydrogen bond to the backbone carbonyl of TrpB is more pronounced. More recent studies suggest that in A3B2, cytisine not only binds at the canonical binding site at the $\alpha^{+} / \beta^{-}$-interface, but also at the $\alpha / \alpha$-interface. ${ }^{40}$

Several variants on the cytisine structure did not maintain the ability to activate $\mathrm{nAChRs}$. Functionalization at $\mathrm{C}(10)$ alone has not yet been studied extensively, but is of interest as substituents at this site are positioned to interact with the complementary subunit in the binding pocket; this region of the binding pocket has been proposed to be most effective in creating subtype selectivity. Recent advances in synthetic strategies have made several C(10)-modified cytisine derivatives available, ${ }^{41,42}$ including some with enhanced selectivity for $\alpha 4 \beta 2$ over $\alpha 3 \beta 4$ and $\alpha 7{ }^{36,37,43}$ More recently, direct C-H functionalization of cytisine itself has increased both the accessibility and range of $\mathrm{C}(10)$-variants that are available, and these can now be synthesized (for the first time) in enantiomerically-pure form. ${ }^{43}$

Because of its rigid structure and some existing structural information, cytisine provides an excellent platform for probing the agonist binding site of the nAChR. In the present study, we set out to evaluate the key binding interactions between cytisine and the binding site of $\alpha 4 \beta 2 \mathrm{nAChR}$ and how those interactions are impacted by the $\mathrm{C}(10)$-modifications of cytisine. To achieve this goal, we used two-electrode voltage-clamp electrophysiology and non-canonical amino acid mutagenesis. In contrast to the well-studied agonists nicotine and acetylcholine, cytisine and the $\mathrm{C}(10)$-derivatives make a second cation- $\pi$ interaction to TyrC2. Double-mutant cycle analyses revealed that this cation$\pi$ interaction to $\mathrm{TyrC} 2$ is the binding parameter most strongly impacted by pyridone ring-substitution, with the hydrogen bond to LeuE in the complementary subunit (and associated with the pyridone $\mathrm{C}=\mathrm{O}$ as the hydrogen bond acceptor) being second in impact. Interestingly, pyridone substitution generally enhances the TyrC2 cation- $\pi$ interaction but diminishes the LeuE hydrogen bond.

\section{RESULTS AND DISCUSSION}

Recently, we have shown that, along with the three binding interactions mentioned above, some agonists make a second cation- $\pi$ interaction at TyrC2 in $\alpha 4 \beta 2$ (Figure 1). ${ }^{44}$ The particular agonists are metanicotine, TC299423, varenicline, and nornicotine, all of which are secondary ammonium agonists, unlike nicotine or ACh. Since, cytisine also contains a protonatable secondary amine (pKa $\geq 7.8),{ }^{25}$ we hypothesized that this secondary cation $-\pi$ interaction could be similarly relevant for cytisine binding to $\alpha 4 \beta 2$.

To test for a cation- $\pi$ interaction at $\mathrm{TyrC} 2$, nonsense-suppression-based fluorination studies were conducted. In these experiments, the codon for Y202 was mutated to a TAG stop codon. In vitro transcribed mutant mRNA was injected into Xenopus laevis oocytes alongside bioorthogonal tRNA $\mathrm{CUA}_{\mathrm{CA}}$ that has been chemically coupled to a non-canonical amino acid. To probe for the cation- $\pi$ interaction, Y202 was replaced by a series of residues with electron withdrawing groups on the aromatic side chain to weaken the interaction. Historically, a series of fluorinated phenylalanines $\left(\mathrm{F}_{\mathrm{n}} \mathrm{Phe}\right)$ have been used to probe Tyr residues, as directly fluorinating tyrosine causes the phenol group to deprotonate at physiological $\mathrm{pH}$. This strategy has been used successfully for several receptor/agonist combinations. Concentration-response curves were determined using two-electrode voltage clamp electrophysiology. So-called fluorination plots show the relationship of $\mathrm{EC}_{50}$ to the calculated gas-phase cation- $\pi$ interaction strength. Typically, when a cation- $\pi$ interaction is present, a linear correlation is observed.

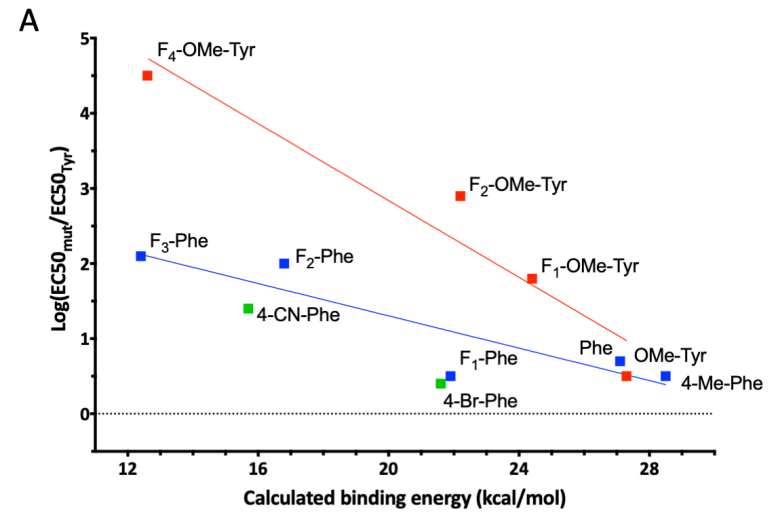

B

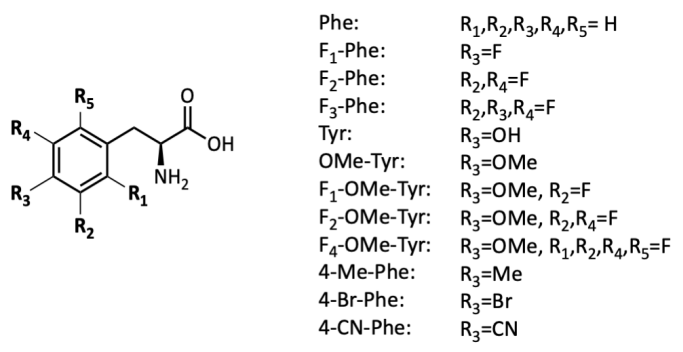

Figure 2. Fluorination plot for cytisine at $\mathrm{TyrC} 2$ in the $\mathrm{A} 3 \mathrm{~B} 2$ stoichiometry. (A) Fluorination plot showing $\mathrm{F}_{\mathrm{n}}$-Phe series in blue $\left(\mathrm{R}^{2}=0.80\right), \mathrm{F}_{\mathrm{n}}-\mathrm{OMe}-\mathrm{Tyr}$ series in red $\left(\mathrm{R}^{2}=0.92\right)$, and $\mathrm{CN}-\mathrm{Phe}$ and $\mathrm{Br}-\mathrm{Phe}$ in green. The $\mathrm{x}$-axis is the calculated binding energy between $\mathrm{Na}^{+}$and each side chain in the gas phase..$^{45}$ The y-axis is the $\log$ fold shift in $\mathrm{EC}_{50}$. (B) Fluorinated amino acids used in this experiment. $\mathrm{R}=\mathrm{H}$ unless explicitly stated. 
Substituting TyrC2 in A3B2 for fluorinated phenylalanines produced substantial $\mathrm{EC}_{50}$ shifts for cytisine as compared to Phe, but the observed trend was not as linear as is typically seen (Figure 2, Table 1). Mutating Tyr (wild type) to Phe gives a 5.1 fold loss of function, larger than usual, suggesting that the C(4) hydroxyl might be important either as a hydrogen bonding group or just for its steric bulk. In addition, the shift seen for $\mathrm{F}_{1}$ Phe is smaller than expected (3.2 fold), which could be explained by the fluorine partially rescuing the need for steric bulk at the 4-position that is lacking at Phe. Lack of steric bulk at the 4-position in $\mathrm{F}_{2}$-Phe yields a larger loss of function than expected (106 fold) based on electrostatics alone. To investigate whether the $\mathrm{C}(4)$ hydroxyl forms a hydrogen bond, we also tested OMe-Tyr and 4-Me-Phe. Both mutants have $\mathrm{EC}_{50}$ values closer to wild type than Phe, suggesting that steric effects at the $\mathrm{C}(4)$ position play a role. To further confirm the idea of a cation$\pi$ interaction, we tested 4-CN-Phe and 4-Br-Phe (Figure 2, Table 1). These residues are nearly isosteric, but 4-CN-Phe is much more deactivating than $\mathrm{Br}-\mathrm{Phe}$. Their respective fold shifts in $\mathrm{EC}_{50}, 26$ and 2.3, support the argument for a cation- $\pi$ interaction.

Table 1. Cytisine $\mathrm{EC}_{50}$ values for non-canonical amino acids at $\mathrm{TyrC} 2$ in $\mathrm{A} 3 \mathrm{~B} 2$.

\begin{tabular}{|c|c|c|c|c|c|c|}
\hline Residue & $\mathrm{EC}_{50}(\mu \mathrm{M})$ & $\mathbf{n}_{\mathrm{H}}$ & & $\begin{array}{l}\text { Fold } \\
\text { shift }\end{array}$ & $\mathbf{N}$ & $\left|\mathbf{I}_{\max }\right|$ \\
\hline Tyr & $0.0013 \pm 0.00002$ & 1.9 & \pm 0.05 & 1.0 & 12 & $0.22-27$ \\
\hline Phe & $0.0066 \pm 0.0001$ & 1.4 & \pm 0.04 & 5.1 & 13 & $0.064-22$ \\
\hline $\mathrm{F}_{1}$-Phe & $0.0042 \pm 0.0002$ & 1.6 & \pm 0.08 & 3.2 & 13 & $0.34-20$ \\
\hline $\mathrm{F}_{2}$-Phe & $0.14 \pm 0.01$ & 1.2 & \pm 0.04 & 110 & 14 & $0.29-9.5$ \\
\hline $\mathrm{F}_{3}$-Phe & $0.16 \pm 0.006$ & 1.1 & \pm 0.05 & 120 & 13 & $0.44-8.0$ \\
\hline 4-Br-Phe & $0.0031 \pm 0.00007$ & 1.7 & \pm 0.06 & 2.3 & 14 & $0.09-8.3$ \\
\hline 4-CN-Phe & $0.034 \pm 0.0009$ & 1.3 & \pm 0.04 & 26 & 16 & $0.14-14$ \\
\hline 4-Me-Phe & $0.0037 \pm 0.0002$ & 1.6 & \pm 0.1 & 2.8 & 14 & $0.08-15$ \\
\hline OMe-Tyr & $0.0045 \pm 0.0001$ & 1.4 & \pm 0.04 & 3.5 & 15 & $0.60-27$ \\
\hline \multicolumn{2}{|c|}{$\mathrm{F}_{1}$-OMe-Tyr $0.077 \pm 0.002$} & 1.3 & \pm 0.04 & 59 & 16 & $2.0-8.9$ \\
\hline \multicolumn{2}{|c|}{$\mathrm{F}_{2}$-OMe-Tyr $1.1 \quad \pm 0.05$} & 0.95 & $5 \pm 0.04$ & 850 & 11 & $0.16-3.7$ \\
\hline \multicolumn{2}{|c|}{$\mathrm{F}_{4}$-OMe-Tyr $42 \quad \pm 3$} & & \pm 0.07 & 32000 & & $\begin{array}{l}0.03- \\
0.20\end{array}$ \\
\hline
\end{tabular}

In an effort to obtain a more detailed fluorination plot for cytisine, we tested a series of fluorinated OMe-Tyr $\left(\mathrm{F}_{\mathrm{n}}-4-\mathrm{OMe}-\right.$ Tyr). This series shows that having a constant substituent at $\mathrm{C}(4)$ yields a clear linear trend, further corroborating the cation$\pi$ interaction (Figure 2, Table 1). To confirm that this interaction is present in both $\alpha 4 \beta 2$ stoichiometries, TyrC2 in $\mathrm{A} 2 \mathrm{~B} 3$ was also substituted with the fluorinated phenylalanine series (Phe, $\mathrm{F}_{1} \mathrm{Phe}, \mathrm{F}_{2}-\mathrm{Phe}, \mathrm{F}_{3}-\mathrm{Phe}$ ). The fluorination plot for $\mathrm{A} 2 \mathrm{~B} 3 \mathrm{resem}-$ bled that observed for A3B2 (Figure S1, Table S1). Thus, cytisine continues the trend that agonists containing a protonated secondary amine make dual cation- $\pi$ interactions.

All substituted cytisines show a substantial loss of function for $\mathrm{F}_{3}$-Phe relative to Phe at TyrC2. This confirms that all the compounds studied here make a dual cation- $\pi$ interaction in the $\alpha 4 \beta 2 \mathrm{nAChR}$.
Impact of cytisine $\mathbf{C}(10)$-modification on $\mathbf{E C}_{50}$ and efficacy. Identifying the second cation- $\pi$ interaction to TyrC 2 expanded the binding model for cytisine, and consequently added to the list of agonists exhibiting this new binding pattern. Previous work has shown that there is variation in the standard binding model, including the lack of a backbone hydrogen bond to $\operatorname{TrpB}$ for $\mathrm{ACh}$, and the absence of a functionally important LeuE hydrogen bond for varenicline. ${ }^{39}$ We hypothesized that making subtle, systematic changes to the cytisine structure would allow us to manipulate the individual binding interactions more precisely than simply comparing more structurally diverse agonists. The $C(9)$ and $C(10)$ positions are shown in Figure $3 \mathrm{~B}$. Based on structural studies of the ACh binding protein $(\mathrm{AChBP})$, functionalization at $\mathrm{C}(10)$ is expected to interact with the complementary subunit in the binding pocket and could provide relevant information on subtype selectivity. ${ }^{46} \mathrm{In}$ deed, in binding affinity studies some of these compounds have enhanced selectivity for $\alpha 4 \beta 2$ over $\alpha 3 \beta 4$ and $\alpha 7 .^{43}$ We therefore selected a series of $\mathrm{C}(10)$-modified cytisine derivatives to test our hypothesis (Figure 3).
A

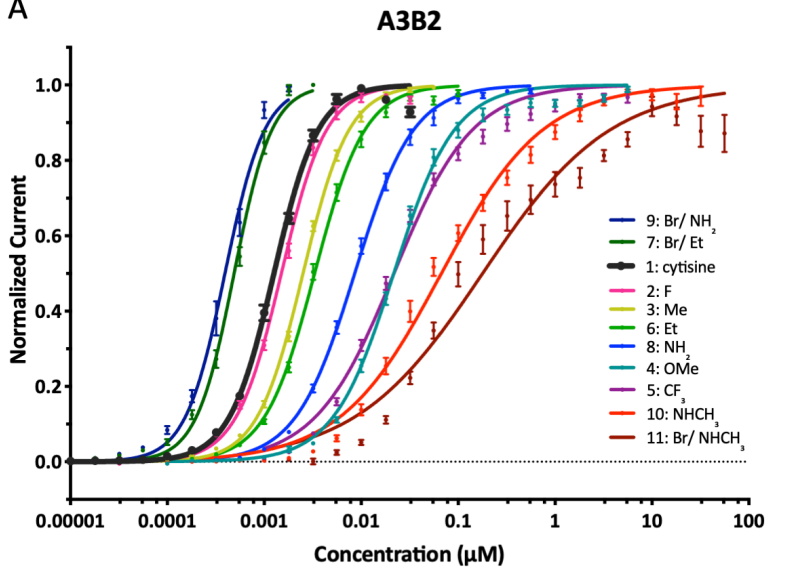

B

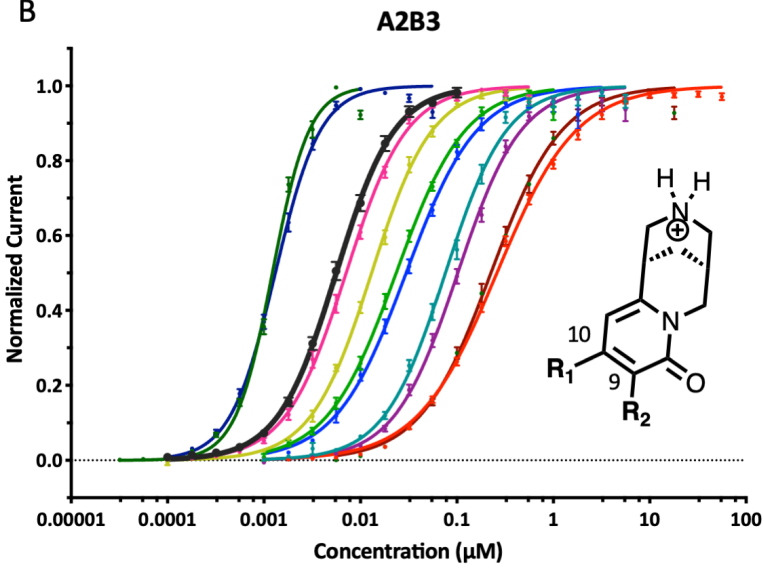

Figure 3. Dose-response curves of cytisine derivatives in the two stoichiometries of $\alpha 4 \beta 2$; (A) A3B2 and (B) A2B3. Inset in B shows the structure of cytisine with $C(9)$ and $C(10)$ highlighted. All single substituents correspond to $\mathrm{R} 1$ at the $\mathrm{C}(10)$-position, for which $\mathrm{R}_{2}=$ H. $C(9) / C(10)$ disubstituted variant have $R_{2}=B r$. Note that the dose-response curve for $\mathbf{1 1}\left(\mathrm{Br} / \mathrm{NHCH}_{3}\right)$ in $\mathrm{A} 3 \mathrm{~B} 2$ is presented here with a monophasic fit, but values in Table 2 reflect $\mathrm{EC}_{50}$ and Hill coefficients obtained through a biphasic fit. 
Table 2. $\mathrm{EC}_{50}$ values for cytisine derivatives at WT A3B2.

\begin{tabular}{|c|c|c|c|c|c|c|}
\hline Ligand & $\mathrm{EC}_{50}(\mathrm{nM})$ & $n_{H}$ & Fold shift & $\mathbf{N}$ & Efficacy & $\left|\mathbf{I}_{\max }\right|$ \\
\hline 1 Cytisine & $1.3 \pm 0.02$ & $1.9 \pm 0.05$ & 1.0 & 12 & 0.73 & $0.22-27$ \\
\hline $2 \mathrm{~F}$ & $1.5 \pm 0.07$ & $1.9 \pm 0.05$ & 1.2 & 13 & 0.62 & $1.5-35$ \\
\hline $3 \mathrm{Me}$ & $2.5 \pm 0.2$ & $1.8 \pm 0.04$ & 1.9 & 13 & 0.67 & $0.37-47$ \\
\hline $4 \quad \mathrm{OMe}$ & $22 \pm 1.3$ & $1.4 \pm 0.04$ & 17 & 13 & 0.84 & $0.45-32$ \\
\hline $5 \quad \mathrm{CF}_{3}$ & $22 \pm 0.08$ & $1.1 \pm 0.03$ & 17 & 13 & 0.71 & $1.5-59$ \\
\hline $10 \mathrm{NHCH}_{3}$ & $25 \pm 67$ & $1.5 \pm 0.2$ & 19 & 10 & 0.74 & $6.6-52$ \\
\hline & $530 \pm 160$ & $1.3 \pm 0.4$ & & & & \\
\hline $11 \mathrm{Br} / \mathrm{NHCH}_{3}$ & $60 \pm 40$ & $1.3 \pm 0.2$ & 46 & 12 & 0.84 & $0.89-30$ \\
\hline & $3300 \pm 0.04$ & $3.0 \pm 0.1$ & & & & \\
\hline $\begin{array}{ll}6 & \mathrm{Et}\end{array}$ & $3.3 \pm 0.06$ & $1.7 \pm 0.04$ & 2.5 & 16 & 0.51 & $1.1-36$ \\
\hline $7 \quad \mathrm{Br} / \mathrm{Et}$ & $0.49 \pm 0.1$ & $2.2 \pm 0.1$ & 0.38 & 8 & 0.46 & $0.76-6.8$ \\
\hline $8 \quad \mathrm{NH}_{2}$ & $8.6 \pm 0.2$ & $1.4 \pm 0.04$ & 6.6 & 9 & 0.28 & $0.52-37$ \\
\hline $9 \mathrm{Br} / \mathrm{NH}_{2}$ & $0.39 \pm 0.01$ & $2.1 \pm 0.1$ & 0.3 & 14 & 0.25 & $0.68-23$ \\
\hline
\end{tabular}

Concentration-response curves of all derivatives are presented in Figure 3. Agonist activity was determined in both (A2B3 and A3B2) stoichiometries of $\alpha 4 \beta 2$ and in the $\alpha 7$ homopentamer. The potency for $\alpha 7$ was much lower $(>100 \mu \mathrm{M}$, Figure S2, Table S3) than for $\alpha 4 \beta 2(<1 \mu \mathrm{M})$, so further experiments focused on the two stoichiometries of $\alpha 4 \beta 2$ only. Various substitutions were included in this series, including groups with differing steric and electronic influences. We hypothesized that a $\mathrm{C}(10)$ electron withdrawing or electron donating group would modulate the hydrogen bond acceptor capacity of the pyridone carbonyl. These effects could potentially give opposing $\mathrm{EC}_{50}$ fold shifts. However, all cytisine derivatives with just a single substitution (at $\mathrm{C}(10)$ ) demonstrated decreased potency for both $\alpha 4 \beta 2$ subtypes (Figure 3, Table 2, Table S2). In the A3B2 stoichiometry, the smallest shifts in $\mathrm{EC}_{50}$ relative to cytisine were observed for $\mathbf{2}(\mathrm{F})$ and $\mathbf{3}\left(\mathrm{CH}_{3}\right)$, while the largest shifts in $\mathrm{EC}_{50}$ were observed for $\mathbf{4}\left(\mathrm{OCH}_{3}\right)$ and $\mathbf{1 0}\left(\mathrm{NHCH}_{3}\right)$. Similar trends were seen in the A2B3 stoichiometry. Interestingly, efficacies of all derivatives were higher than cytisine in A2B3, but comparable to cytisine in A3B2. Recall that the parent cytisine is effectively inactive at A2B3, and so it appears that any C(10) substituent renders cytisine viable in the less active stoichiometry.

Efficacy is an important issue here, as the therapeutic benefit of varenicline is thought to arise, at least in part, because it is a partial agonist of the nAChR. Cytisine is a partial agonist at A3B2, and for the most part substitution has only a modest impact on efficacy. Exceptions are compounds 6 -9, which show reduced efficacy. Cytisine shows a very low efficacy at A2B3, and in all cases substitution increases efficacy, although all compounds are still less efficacious at A2B3 than at A3B2.

Given the observed $\mathrm{EC}_{50}$ shifts, we speculated that the decreased potency is actually correlated with increasing size of the substituent, rather than with electronic contribution of this group. To probe this, we tested a series of four additional derivatives with increasing steric bulk, but without substantially

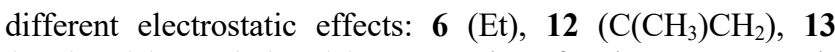
$\left(\mathrm{CH}\left(\mathrm{CH}_{3}\right)_{2}\right), 14\left(\mathrm{C}_{\left.\left(\mathrm{CH}_{3}\right)_{3}\right)}\right) . \mathrm{EC}_{50}$ values for these compounds were increasingly right shifted with increasing size (Figure S3, Table S4). $\log \mathrm{P}$ and $\log \mathrm{D}$ do not yield any correlation with the $\mathrm{EC}_{50}$ fold shifts (Figure S5).

Addition of a bromine at the $\mathrm{C}(9)$ position results in a substantial increase in potency, as manifest by a left-shifted $\mathrm{EC}_{50}$, when the $\mathrm{C}(10)$-substituent is an $\mathrm{NH}_{2}$ or Et group (Figure 3). Adding a bromine at $\mathrm{C}(9)$ did not produce the same increase in potency when the $\mathrm{C}(10)$-substituent is $\mathrm{NHCH}_{3}$. In an attempt to explain this difference in activity, we performed HF $6-31 \mathrm{G}^{* *}$ calculations on both structures. Ligands $7(\mathrm{Br} / \mathrm{Et})$ and 11 $\left(\mathrm{Br} / \mathrm{NHCH}_{3}\right)$ are isosteric, and the electrostatic potentials of the carbonyl and amine are similar as well (Table S5). Conformational analysis indicates that for $\mathbf{1 0}\left(\mathrm{NHCH}_{3}\right)$ and $\mathbf{1 1}$ $\left(\mathrm{Br} / \mathrm{NHCH}_{3}\right)$ the $\mathrm{C}(10)$-substituent stays in the plane of the pyridone ring in the lowest energy conformer, presumably to facilitate conjugation of the nitrogen lone pair with the ring. In contrast, for both $6(\mathrm{Et})$ and $7(\mathrm{Br} / \mathrm{Et})$ the $\mathrm{C}(10)$-substituent is positioned perpendicular to the ring (Figure S4), reflecting what is presumably a steric effect. We speculate that having the $\mathrm{C}(10)$ substituent perpendicular to the ring contributes to the gain in potency that is seen for $7(\mathrm{Br} / \mathrm{Et})$ and $9\left(\mathrm{Br} / \mathrm{NH}_{2}\right)$ relative to 6 (Et) and $8\left(\mathrm{NH}_{2}\right)$. Since the $\mathrm{C}(10)$ substituent in $\mathbf{1 1}$ $\left(\mathrm{Br} / \mathrm{NHCH}_{3}\right)$ is less likely to adopt this conformation, this could prevent favorable repositioning of the ligand resulting in a similar $\mathrm{EC}_{50}$ as $\mathrm{NHCH}_{3}$-cytisine.

Differential Impacts of cytisine C(10)-modification on individual binding interactions. As a global measure of receptor activation, $\mathrm{EC}_{50}$ can be influenced by a number of receptor-independent physico-chemical properties, such as agonist solubility and hydrophobicity. Subtype selectivity, however, is more likely to arise via ligand interactions with side-chain or backbone moieties, and it is those we wish to evaluate. To probe these interactions, we employed strategies based on non-canonical amino acid incorporation (Figure 4) as described 
previously. ${ }^{17,39}$ To probe the TrpB cation- $\pi$ interaction, we replaced W154 by F4-Trp. ${ }^{47}$ To test hydrogen bonding to the backbone carbonyl of this residue, we substitute the $i+1$ residue, T155, with its $\alpha$-hydroxy analogue, Tah (threonine, $\alpha$-hydroxy). ${ }^{16,48}$ To test the hydrogen bond to LeuE in the $\beta 2$ subunit, L119 is replaced by Lah (Leucine, $\alpha$-hydroxy).${ }^{15}$ To probe the TyrC2 cation- $\pi$ interaction, we replaced $\mathrm{Y} 202$ with $\mathrm{F}_{3}$-Phe. To quantify the functional effect of a mutant, we calculate the $\mathrm{EC}_{50}$ fold shift, which is $\mathrm{EC}_{50}$ for the mutant receptor divided by wild type recovery response (i.e., producing wild type receptor by incorporating the wild type residue by nonsense suppression). We typically consider an $\mathrm{EC}_{50}$ fold shift larger than 2 as meaningful. All $\mathrm{EC}_{50}$ fold shifts observed for the four binding interactions are larger than 2 , indicating that all derivatives make all four binding interactions. $\mathrm{EC}_{50}$ values and Hill coefficients for non-canonical amino acid mutagenesis are reported in Tables S6-S9 for A3B2 and Tables S10-S13 for A2B3.
A

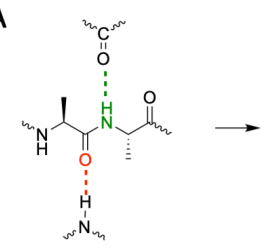

B
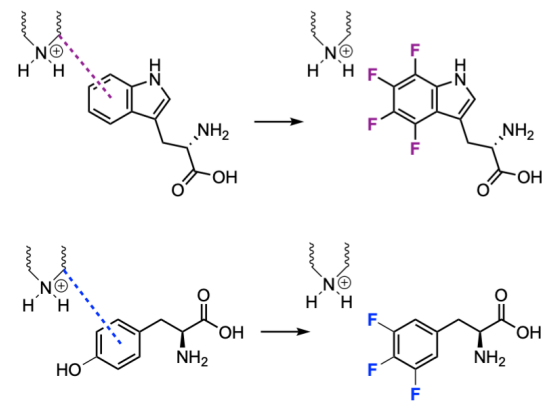

C
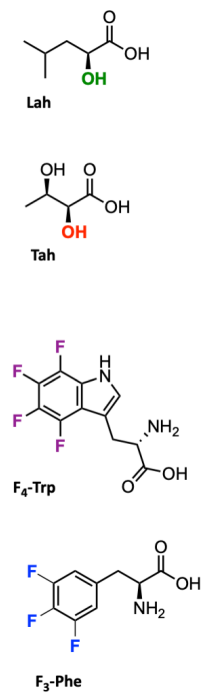

Figure 4. Strategy to selectively probe electrostatic interactions contributing to binding of the ligand. (A) To probe backbone hydrogen bonds, $\alpha$-hydroxy acids are incorporated resulting in the loss of hydrogen bond donor (backbone $\mathrm{NH}$ ) and weakened hydrogen bond acceptor (backbone carbonyl). (B) To probe cation- $\pi$ interactions Trp and Tyr are substituted by a series of fluorinated derivatives. (C) Non-canonical amino acids used in this study; $\alpha$ hydroxy acid of Thr (Tah), $\alpha$-hydroxy acid of Leu (Lah), $\mathrm{F}_{4}$-Trp, $\mathrm{F}_{3}$-Phe.

To study how cytisine modification has impacted the binding interactions relative to cytisine, we have employed double-mutant cycle analyses. Typically, mutant cycle analyses have probed coupling between two amino acids in a protein ${ }^{49}$ but we have found the methodology useful when one mutation is to the protein and the other is to the ligand. ${ }^{15,44}$ Here, we performed a similar analysis to determine if the four known binding interactions are more or less important for the binding of the substituted cytisines and to quantify this effect in terms of free energy. In this mutant cycle analysis, the first mutant is the incorporation of a non-canonical amino acid, either $\mathrm{F}_{4}$-Trp, Tah, Lah or $\mathrm{F}_{3}$-Phe, probing for one of the four key binding interactions. The second 'mutant' is a cytisine analogue, one of the C(10)modified cytisines; a representative analysis is presented in Figure 5. The extent to which the two perturbations are additive or nonadditive is expressed by the coupling constant $\Omega$, which can be converted into coupling energy using the equation $\Delta \Delta \mathrm{G}=$ $\mathrm{RT} \ln (\Omega)$. Functional coupling between the two perturbations is observed when $\Delta \Delta \mathrm{G}$ is non-zero. In the present system a positive $\Delta \Delta \mathrm{G}$ means that the protein mutation causes a larger loss of function for the new agonist than is observed for cytisine (or the increased potency of the new agonist is smaller than cytisine). This suggests the binding interaction being probed is stronger/more important for binding of the new agonist than for the binding of cytisine. When the $\Delta \Delta \mathrm{G}$ value is negative, the protein mutation causes a smaller loss of function for the new agonist than for cytisine (or the gain of function by the new agonist is larger). This suggests the probed interaction is weaker/less important for the new agonist. We generally consider a coupling of at least 2-fold to be meaningful, which corresponds to $|\Delta \Delta \mathrm{G}|>0.4 \mathrm{kcal} / \mathrm{mol}$.

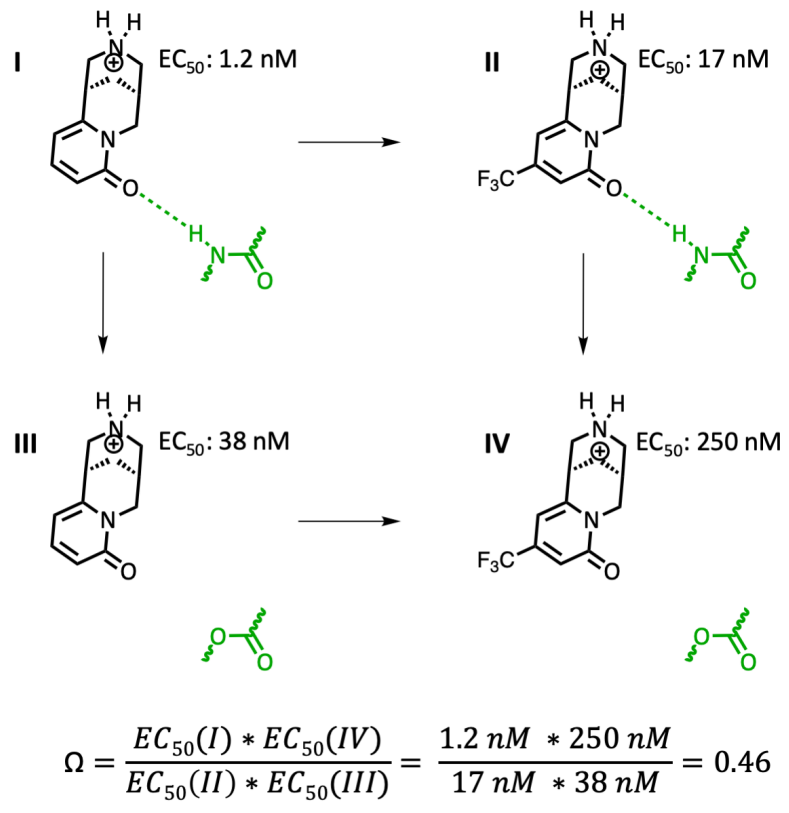

\section{$\Delta \Delta G=R T \ln (0.46)=-0.43 \mathrm{kcal} / \mathrm{mol}$}

Figure 5. Double-mutant cycle analysis. Ligand $\mathbf{5}\left(\mathrm{CF}_{3}\right)$ is used as an example. $\mathrm{EC}_{50} \mathrm{I}$ reflects the response of cytisine with the wildtype amino acid. $\mathrm{EC}_{50} \mathrm{II}$ and $\mathrm{EC}_{50} \mathrm{III}$ both reflect one perturbation; cytisine derivative $\mathbf{5}\left(\mathrm{CF}_{3}\right)$ with wild-type residue and cytisine with the non-canonical amino acid (Lah) respectively. $\mathrm{EC}_{50} \mathrm{IV}$ corresponds to the "double mutant" where the response is measured for the cytisine derivative with the non-canonical amino acid present. The impact of substitution in terms of energy is calculated using the equation $\Delta \Delta \mathrm{G}=\mathrm{RT} \ln (\Omega)$.

Before considering specific compounds, it is useful to examine general trends across the series. Even with simple substituents, many features of a molecule can change. By inspecting the total series, one can discern more general features. This is aided by the presentation in Figure 6 . The $\Delta \Delta \mathrm{G}$ values observed here range from -1.62 to $1.27 \mathrm{kcal} / \mathrm{mol}$. Recall that we are looking at the differences in contributions of individual binding interactions to the binding of $\mathrm{C}(10)$ - and $\mathrm{C}(9) \mathrm{C}(10)$-substituted cytisine variants relative to cytisine, so there are some quite meaningful variations. To be clear, all derivatives still engage in the specific interaction being probed, but our focus is on how the magnitudes of those interactions differ from the same interaction with cytisine. 
Similar trends are seen for the two $\alpha 4 \beta 2$ stoichiometries, although the effects are generally stronger for the A3B2 arrangement. This is seen by the larger fraction of coupling energies that rise of above the $|\Delta \Delta \mathrm{G}|>0.4 \mathrm{kcal} / \mathrm{mol}$ threshold. The cation$\pi$ interaction to TyrC2 generally appears to be of greater importance in the $\mathrm{C}(10)$-derivatives than for cytisine, in that meaningful, positive coupling energies are observed in both stoichiometries for almost all agonist-receptor pairings. The cation- $\pi$ interaction to $\operatorname{TrpB}$ is generally less perturbed by substitution, especially, again, in the A2B3 stoichiometry (Figure $6)$.

Considering the two hydrogen bonding interactions probed, the hydrogen bond to LeuE (which involves the pyridone $\mathrm{C}=\mathrm{O}$ as an acceptor) is generally weakened by $\mathrm{C}(10)$ substitution, and again the effect is largest in the A3B2 stoichiometry. As with the cation- $\pi$ interaction to $\operatorname{TrpB}$, the hydrogen bond to the TrpB carbonyl is less influenced by pyridone ring-substitution.

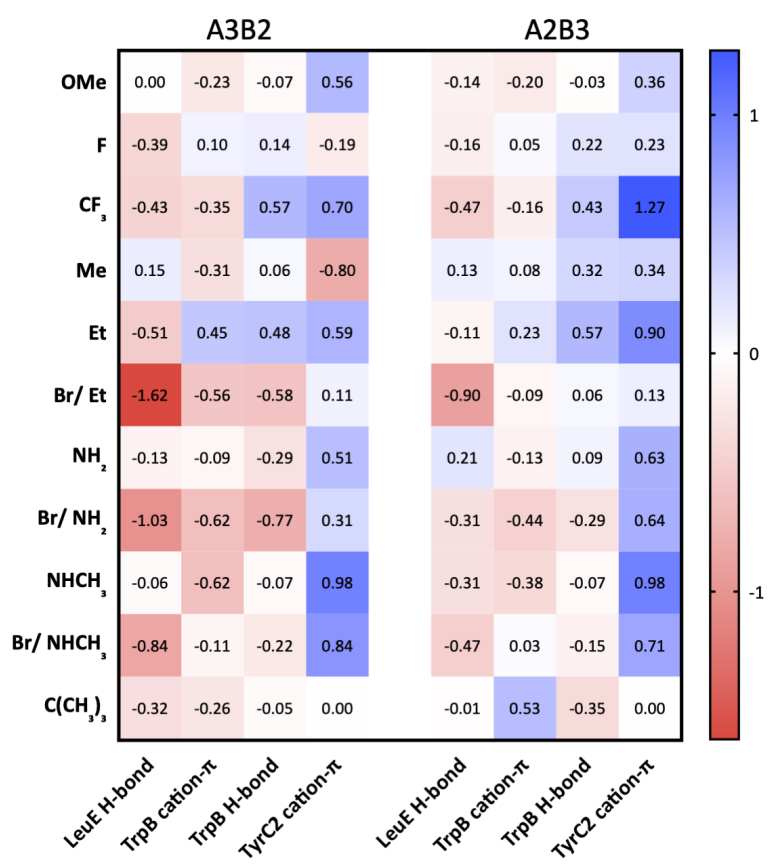

Figure 6. The energetic contributions of cytisine substitution on the individual binding interactions expressed as $\Delta \Delta \mathrm{G}$ values. Values are calculated using the equations in Figure 5.

These global patterns suggest a model for the overall effect that $C(10)$ substitution has on ligand binding. Interactions with TrpB, both the cation- $\pi$ interaction and the backbone hydrogen bond, are not strongly perturbed. This is consistent with the essential role that this protein residue plays in receptor function. Interestingly, the hydrogen bond to LeuE is more frequently weakened, while the cation- $\pi$ interaction to $\mathrm{TyrC} 2$ is strengthened. This suggests that a $\mathrm{C}(10)$ substituent repositions the ligand, away from LeuE (weakening the H-bond in this region) and toward TyrC2 (strengthening the cation- $\pi$ interaction), an adjustment that is depicted in Figure 7 . Thus, by examining a collection of related structures and identifying patterns in receptors responses, we have been able to develop a structural model for how an important class of compounds interacts with a key neuronal receptor.

The largest right shifted $\mathrm{EC}_{50}$ values for the wild type receptor were observed for $\mathbf{1 0}\left(\mathrm{NHCH}_{3}\right)$ and $\mathbf{1 1}\left(\mathrm{Br} / \mathrm{NHCH}_{3}\right)($ Figure $3)$. For $\mathbf{1 0}\left(\mathrm{NHCH}_{3}\right)$ the cation- $\pi$ to $\operatorname{TrpB}$ was weakened and for
$11\left(\mathrm{Br} / \mathrm{NHCH}_{3}\right)$ the hydrogen bond to LeuE was weakened relative to cytisine, but the cation- $\pi$ to TyrC2 was stronger for both (Figure 6). Surprising are the effects seen for 6 (Et) and 7 $(\mathrm{Br} / \mathrm{Et}$ ) (Figure 6). 6 (Et) shows decreased potency compared to cytisine, while $7(\mathrm{Br} / \mathrm{Et})$ shows increased potency. However, the $\Delta \Delta \mathrm{G}$ values of three individual binding interactions are positive for $\mathbf{6}(\mathrm{Et})$, while these are negative for $7(\mathrm{Br} / \mathrm{Et})$, suggesting stronger interactions in $\mathbf{6}(\mathrm{Et})$ than $7(\mathrm{Br} / \mathrm{Et})$. Based on wildtype $\mathrm{EC}_{50}$ fold shift alone, one might have expected the opposite. A similar trend is seen for $\mathbf{8}\left(\mathrm{NH}_{2}\right)$ and $\mathbf{9}\left(\mathrm{Br} / \mathrm{NH}_{2}\right)$. It is unclear what causes this effect. It is possible that other, yet undiscovered, electrostatic interactions are present in the binding pocket, or that new interactions are present for $9\left(\mathrm{Br} / \mathrm{NH}_{2}\right)$ and $7(\mathrm{Br} / \mathrm{Et})$ only. Also, contributions of hydrophobic forces (likely to be significant for a $\mathrm{Br}$ residue) play a role in agonist binding but are not included in this analysis. We do note that simple alkyl substitution such as in $\mathbf{3}(\mathrm{Me})$ and $\mathbf{6}(\mathrm{Et})$ results in only modest changes in $\mathrm{EC}_{50}$. However, these hydrophobic substituents could meaningfully impact physical properties that could produce more useful characteristics regarding bloodbrain barrier penetration and intracellular distribution.
Cytisine

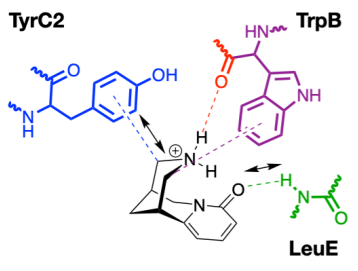

\section{$C(9) / C(10)$-disubstituted cytisine}

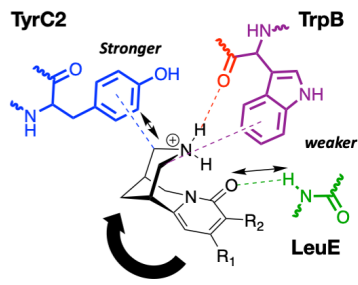

Figure 7. Proposed model based on results in this study. Repositioning of the ligand in a way such that it is closer to TyrC2 and further away from LeuE supports the general trends observed in this study. The $R_{1}$ and $R_{2}$ moieties are at positions $C(10)$ and $C(9)$, respectively. Generally speaking, the cation- $\pi$ interaction with TyrC2 was enhanced, the hydrogen bond with LeuE was diminished, and the two interactions to TrpB appear to be less impacted.

Phe $\mathrm{EC}_{50}$ values sometimes deviate substantially from the wild-type response (Tyr). Some Phe $\mathrm{EC}_{50}$ values are much lower $\left(\mathbf{5}\left(\mathrm{CF}_{3}\right)\right.$ : 0.1 -fold $)$, some are higher $\left(\mathbf{8}\left(\mathrm{NH}_{2}\right)\right.$ 3-fold $)$. This suggests that the hydroxyl of TyrC2 affects binding more for these two compounds than for cytisine. We note again that such a prominent role for the $\mathrm{OH}$ of $\mathrm{TyrC} 2$ has not typically been observed in other studies of nAChRs.

In summary, we used two-electrode voltage-clamp electrophysiology and non-canonical amino acid mutagenesis to probe the agonist binding interactions of a novel series of cytisine derivatives in the $\alpha 4 \beta 2 \mathrm{nAChR}$. In contrast to the well-studied agonists nicotine and acetylcholine, cytisine and the $\mathrm{C}(10)$-substituted cytisine derivatives studied here make a second cation- $\pi$ interaction to TyrC2. Surprisingly, double-mutant cycle analyses revealed that $\mathrm{C}(10)$-derivatives generally make a stronger cation- $\pi$ interaction to TyrC2 than cytisine, whereas the hydrogen bond to LeuE in the complementary subunit is generally diminished. The results suggest a model for how cytisine derivatives adjust their binding orientation within the binding site of $\alpha 4 \beta 2 \mathrm{nAChR}$ in response to pyridone substitution.

Some of the substituted cytisine compounds considered here show potencies that are comparable to the parent compound. It has been suggested ${ }^{25}$ that cytisine has poor penetration into the 
brain. It might be expected that increased hydrophobicity would improve penetration, suggesting some substituted cytisines could have interesting pharmacological properties.

\section{EXPERIMENTAL PROCEDURES}

Molecular biology. Circular DNA of rat nAChR $\alpha 4$ and $\beta 2$ subunits were in a pGEMhe plasmid (wild type expression) and a pAMV plasmid (non-canonical amino acid expression). Sitedirected mutagenesis was performed using the QuickChange protocol (Agilent Stratagene). cDNA in pGEMhe was linearized with restriction enzyme SbfI, whereas cDNA in pAMV was linearized with NotI (New England Biolabs). Purified linear DNA (Qiaquick PCR Purification kit, Qiagen) was then transcribed in vitro using the T7 mMessage Machine kit (Ambion). The resulting mRNA was isolated using the RNeasy RNA purification kit (Qiagen) and quantified by UV-vis spectroscopy (NanoDrop 2000, ThermoFisher Scientific). cDNA and mRNA were stored at $-20^{\circ} \mathrm{C}$ and $-80^{\circ} \mathrm{C}$ respectively.

For non-canonical amino acid incorporation, the residue of interest was mutated to the amber (UAG) stop codon (sites in the $\alpha 4$ subunit) or the opal (UGA) stop codon (sites in the $\beta 2$ subunit). 74-nucleotide THG73 tRNA (for UAG) and 74-nucleotide TQOpS' tRNA (for UGA) were prepared by in vitro transcription from a DNA oligonucleotide template, modified to prevent nontemplated nucleotide addition, using the MEGAshortscript T7 kit (Ambion). ${ }^{50}$ 74-mer tRNA was isolated using Chroma Spin DEPC-H2O columns (Clontech). Hydroxy or amino acid-dCA conjugates were enzymatically ligated to truncated 74-nucleotide TQOpS' tRNA (Lah) or THG73 tRNA (all other non-canonical residues) as described previously. ${ }^{51,52}$ tRNA amino acid or tRNA-hydroxy acid products were confirmed by matrix-assisted laser desorption ionization time-offlight mass spectrometry on a 3-hydroxypicolinic acid matrix. Deprotection of the nitroveratryloxycarbonyl group on the tRNA amino acids was carried out by photolysis for 3 min using a $365 \mathrm{~nm}$ LED (Thorlabs) immediately prior to injection.

For all experiments, $\mathrm{EC}_{50}$ values were obtained using a hypersensitive mutation in the $\alpha 4$ subunit (L9'A). Previous studies report that cytisine is only slightly active at the wild type A2B3 stoichiometry. ${ }^{12}$ However, using the $\alpha 4$ L9' A mutation, we find that cytisine does activate the A2B3 stoichiometry. ${ }^{39,40}$ Besides increasing efficacy, the mutation also yields left shifted $\mathrm{EC}_{50}$ values for both stoichiometries as compared to true wild type, which allows one to probe effects of other mutations or cytisine derivatives. Lastly, the pore mutation results in different rectification between the two stoichiometries; this difference can be determined via-voltage jump experiments to verify which receptor stoichiometry is being observed. ${ }^{16}$ For convenience, what is referred to as wild type receptor is assumed to have the L9'A mutation in the $\alpha 4$ subunit.

Oocyte preparation and injection. Xenopus laevis oocytes (stage V-VI) were harvested and injected with RNAs according to previously described protocols. ${ }^{51}$ Oocytes were injected with 50-75 nl mRNA in nuclease-free water. Post injection, oocytes were incubated at $18^{\circ} \mathrm{C}$ in ND96 solution (96 mM NaCl, 2mM $\mathrm{KCl}, 1 \mathrm{mM} \mathrm{MgCl} 2,1.8 \mathrm{mM} \mathrm{CaCl} 2,5 \mathrm{mM}$ HEPES, pH 7.5) supplemented with $0.05 \mathrm{mg} / \mathrm{ml}$ gentamycin (Sigma), $2.5 \mathrm{mM}$ sodium pyruvate (Acros Organics), and $0.67 \mathrm{mM}$ theophylline (Sigma).

For expression of wild-type $\alpha 4 \beta 2$ receptors, $\alpha 4 \mathrm{~L}$ 9'A and $\beta 2$ mRNA were mixed in $1: 3$ or $10: 1$ ratio by mass to obtain the A2B3 and A3B2 stoichiometry, respectively. Each cell was injected with $25 \mathrm{ng}$ mRNA in a single injection and incubated for $24 \mathrm{~h}$ before recording.

For non-canonical amino acid incorporation into the $\alpha$ subunit, $\alpha 4 L^{2}$ ' $A$ and $\beta 2$ mRNA were mixed in a 3:1 ratio for expression of A2B3 and a 100:1 ratio by mass for expression of A3B2 receptors. One exception to this was the incorporation of Phe and $\mathrm{F}_{3}$-Phe into the $\alpha$-subunit, where a ratio of 150:1 was used for expression of A3B2. For non-canonical amino acid incorporation into the $\beta$-subunit, $\alpha 4 \mathrm{~L}$ 9' $\mathrm{A}$ and $\beta 2 \mathrm{mRNA}$ were mixed in a 1:40 ratio for expression of $\mathrm{A} 2 \mathrm{~B} 3$ and a 10:1 ratio by mass for expression of $\mathrm{A} 3 \mathrm{~B} 2$ receptors. mRNA mixtures and deprotected tRNA were mixed in a 1:1 volume ratio prior to injection. In cases where $24 \mathrm{~h}$ incubation resulted in responses too low for systematic study, a second injection of mRNA and tRNA was performed and cells were incubated for a total of $48 \mathrm{~h}$ before recording.

The reliability of the non-canonical amino acid incorporation was confirmed through read-through/reaminoacylation experiments as previously described. ${ }^{39}$ Briefly, the fidelity of non-canonical amino acid incorporation was confirmed at each site by a wild-type recovery experiment in which the tRNA was charged with the wild-type residue. If the wild-type recovery yielded concentration-response relations resembling wild type, desired incorporation for the non-canonical residue was assumed also. As a negative control, unacylated 76-mer tRNA with mRNA was injected alongside the mutant and wild-type recovery conditions. Negligible current from the unacylated 76mer injection confirmed the lack of undesirable reaminoacylation events.

Chemical preparation. (-)-Cytisine was purchased from Sigma, and all cytisine derivatives were synthesized.

Whole-cell electrophysiology. All electrophysiological recordings were performed using the OpusXpress 6000A (Axon Instruments) in two-electrode voltage clamp mode at ambient temperature $\left(20-25^{\circ} \mathrm{C}\right)$. Oocytes were impaled with borosilicate glass pipettes filled with $3 \mathrm{M} \mathrm{KCl}(\mathrm{R}=0.3-3.0 \mathrm{M} \Omega)$ and clamped at a holding potential of $-60 \mathrm{mV} . \mathrm{Ca}^{2+}$ free ND96 solution was used as running buffer. Agonists were prepared in in $\mathrm{Ca}^{2+}$ free ND96 and $1 \mathrm{~mL}$ was applied over $15 \mathrm{~s}$ followed by a 2 min washout with buffer at a rate of $3 \mathrm{~mL} \mathrm{min-1} \mathrm{(chamber}$ volume, $500 \mu \mathrm{L}$ ). For $\mathrm{Br} / \mathrm{NH}_{2}$-cytisine and $\mathrm{Br} /$ Et-cytisine, which cause slower deactivation, the washout duration post agonist application was extended to $5 \mathrm{~min}$. Dose-response measurements were performed using a series of $\sim 2$-fold concentration steps, spanning multiple orders of magnitude, for a total of 8-24 doses. Data for each mutant and agonist combination were obtained from at least two different batches of oocytes. Efficacy experiments involved testing of two to three maximally activating acetylcholine concentrations, followed by the maximally activating concentration of the test compound of interest, followed by two doses of acetylcholine. Data were sampled at 50 $\mathrm{Hz}$. Voltage-jump experiments were performed to verify receptor stoichiometry of wild-type and mutant receptors as described previously. ${ }^{16}$

Data analysis. Two-electrode voltage-clamp traces were processed in Clampfit 10.3 (Axon Instruments). Raw traces were filtered using a low pass Gaussian filter at $5 \mathrm{~Hz}$, followed by a subtraction of the average baseline current preceding agonist application. Normalized peak currents were averaged and fit to the Hill equation, $\mathrm{I}_{\text {norm }}=1 /\left(1+\left(\mathrm{EC}_{50} /[\right.\right.$ agonist $\left.] \mathrm{n}_{\mathrm{H}}\right)$ in Prism 8 (GraphPad Software, Inc.), where $\mathrm{I}_{\text {norm }}$ is the normalized peak current at a given agonist concentration, $\mathrm{EC}_{50}$ is the agonist 
concentration that elicits a half-maximum response, and $n_{H}$ is the Hill coefficient. Peak currents were normalized to the maximum current observed for that cell. Some compounds showed a biphasic dose-response relation; these data were fitted to a biphasic dose-response equation, $\mathrm{I}_{\text {norm }}=1 * \mathrm{frac} /(1+$ $10\left(\left(\operatorname{logEC} 50 \_1-\log [\right.\right.$ agonist $\left.\left.\left.]\right) * \mathrm{n}_{\mathrm{H} 1}\right)\right)+1 *(1-$ frac $) /(1$

$10\left(\left(\operatorname{logEC} 50^{-} 2-\log [\right.\right.$ agonist $\left.\left.\left.]\right) * \mathrm{n}_{\mathrm{H} 2}\right)\right)$, where EC50 1 and EC50_2 correspond to $n_{\mathrm{H} 1}$ and $n_{\mathrm{H} 2}$, respectively. The efficacy of compounds was measured as $\mathrm{I}_{\max }$ of the compound divided by the Imax of acetylcholine. Unless otherwise stated, $\mathrm{EC}_{50}$ and $\mathrm{n}_{\mathrm{H}}$ data are shown as mean \pm standard error of the mean (SEM). Coupling energies for double-mutant cycles were calculated using the equation: $\Delta \Delta \mathrm{G}=-\mathrm{R}^{*} \mathrm{~T}^{*} \ln ((\mathrm{EC} 50 \mathrm{WT}$-cyt*EC50 mutligand)/ (EC50 WT-ligand*EC50 mut-cyt)), where R is the gas constant, $\mathrm{T}$ is temperature, cyt is cytisine, mut denotes mutant, and ligand refers to the various cytisine derivatives used in this study. The value for T used here was $298 \mathrm{~K}$. Geometry and electrostatics calculation were performed in Spartan. $\operatorname{LogD}$ values were calculated using ACD/Percepta Platform, Advanced Chemistry Development, Inc., Toronto, ON, Canada, www.acdlabs.com, 2019.

Compounds $10\left(\mathrm{NHCH}_{3}\right)$ and $11\left(\mathrm{Br} / \mathrm{NHCH}_{3}\right)$ exhibit a biphasic response in $\mathrm{A} 3 \mathrm{~B} 2$, representing two distinct binding sites: binding at the $\alpha / \beta$-interface and at the $\alpha / \alpha$-interface. For the purpose of calculating fold shifts and to make comparisons with other derivatives, we solely used the first $\mathrm{EC}_{50}$, assuming the binding site at the $\alpha / \beta$-interface is always the highest affinity one.

\section{ASSOCIATED CONTENT}

\section{Supporting Information}

Figures S1-S5 and Tables S1-S13, as well as procedures for the syntheses of cytisine derivatives and their ${ }^{1} \mathrm{H}$ and ${ }^{13} \mathrm{C}$ NMR data. The Supporting Information is available free of charge on the ACS Publications website.

\section{AUTHOR INFORMATION}

\section{Corresponding Author \\ *dadougherty@caltech.edu}

\section{ORCID}

Dennis A. Dougherty: 0000-0003-1464-2461

\section{Author Contributions}

All authors have revised and given approval to the final version of the manuscript.

\section{Notes}

The authors declare no competing financial interests.

\section{ACKNOWLEDGMENT}

We thank Dr. Aurelian Honraedt for help in the synthesis of the derivatives. We thank Dr. Justin A. Hilf and Prof. Brian Stoltz for their assistance in calculating $\log \mathrm{D}$ values. We thank Achieve Life Sciences for their generous gift of (-)-cytisine, and the University of Bristol and Engineering and Physical Sciences Research Council (EP/N024117/1) for financial support. This work was partially supported by funds provided by The Regents of the University of California, Research Grants Program Office, Tobacco Related Disease Research Program, Grant Number T29IR0445. The opinions, findings, and conclusions herein are those of the author and not necessarily represent those of The Regents of the University of California, or any of its programs.

\section{ABBREVIATIONS}

$\mathrm{nAChR}$, nicotinic acetylcholine receptor; $\mathrm{ACh}$, acetylcholine.

\section{REFERENCES}

(1) Jensen, A. A.; Frølund, B.; Liljefors, T.; Povl, K.-L. Neuronal Nicotinic Acetylcholine Receptors: Structural Revelations, Target Identifications, and Therapeutic Inspirations. J Med Chem 2005, 48 (15), 4705-4745. https://doi.org/10.1021/jm040219e.

(2) Gotti, C.; Zoli, M.; Clementi, F. Brain Nicotinic Acetylcholine Receptors: Native Subtypes and Their Relevance. Trends Pharmacol. Sci. 2006, $27 \quad$ (9), $482-491$. https://doi.org/10.1016/j.tips.2006.07.004.

(3) World Health Organization. WHO Report on the Global Tobacco Epidemic, 2017: Monitoring Tobacco Use and Prevention Policies; World Health Organization: Geneva, 2017.

(4) United States Surgeon General. The Health Consequences of Smoking -- 50 Years of Progress: A Report of the Surgeon General: (510072014-001), 2014. https://doi.org/10.1037/e510072014-001.

(5) Xu, X.; Bishop, E. E.; Kennedy, S. M.; Simpson, S. A.; Pechacek, T. F. Annual Healthcare Spending Attributable to Cigarette Smoking: An Update. Am. J. Prev. Med. 2015, 48 (3), 326-333. https://doi.org/10.1016/j.amepre.2014.10.012.

(6) Brunzell, D. H.; Stafford, A. M.; Dixon, C. I. Nicotinic Receptor Contributions to Smoking: Insights from Human Studies and Animal Models. Curr Addict Rep. 2015, 2 (1), 33-46. https://doi.org/10.1007/s40429-015-0042-2.

(7) Lester, H. A.; Xiao, C.; Srinivasan, R.; Son, C. D.; Miwa, J.; Pantoja, R.; Banghart, M. R.; Dougherty, D. A.; Goate, A. M.; Wang, J. C. Nicotine Is a Selective Pharmacological Chaperone of Acetylcholine Receptor Number and Stoichiometry. Implications for Drug Discovery. 2009, 11 (1), 167-177.

(8) Hogg, R.; Bertrand, D. Nicotinic Acetylcholine Receptors as Drug Targets. Curr. Drug Targets CNS Neurol Disord 2004, 3 (2), $123-130$.

(9) Gotti, C.; Clementi, F. Neuronal Nicotinic Receptors: From Structure to Pathology. Prog. Neurobiol. 2004, 74 (6), 363-396.

(10) Nelson, M. E.; Kuryatov, A.; Choi, C. H.; Zhou, Y.; Lindstrom, J. Alternate Stoichiometries of Alpha4beta2 Nicotinic Acetylcholine Receptors. Mol Pharmacol 2003, 63 (2), 332-341.

(11) Wang, J.; Kuryatov, A.; Sriram, A.; Jin, Z.; Kamenecka, T. M.; Kenny, P. J.; Lindstrom, J. An Accessory Agonist Binding Site Promotes Activation of A4 $\beta 2 *$ Nicotinic Acetylcholine Receptors. $J$ Biol Chem 2015, $290 \quad$ (22), 13907-13918. https://doi.org/10.1074/jbc.M115.646786.

(12) Moroni, M.; Zwart, R.; Sher, E.; Cassels, B. K.; Bermudez, I. Alpha4beta2 Nicotinic Receptors with High and Low Acetylcholine Sensitivity: Pharmacology, Stoichiometry, and Sensitivity to LongTerm Exposure to Nicotine. Mol Pharmacol 2006, 70 (2), 755-768. https://doi.org/10.1124/mol.106.023044.

(13) Son, C. D.; Moss, F. J.; Cohen, B. N.; Lester, H. A. Nicotine Normalizes Intracellular Subunit Stoichiometry of Nicotinic Receptors Carrying Mutations Linked to Autosomal Dominant Nocturnal Frontal Lobe Epilepsy. Mol Pharmacol 2009, 75 (5), 1137-1148. https://doi.org/10.1124/mol.108.054494.

(14) Weltzin, M. M.; Lindstrom, J. M.; Lukas, R. J.; Whiteaker, P. Distinctive Effects of Nicotinic Receptor Intracellular-Loop Mutations Associated with Nocturnal Frontal Lobe Epilepsy. Neuropharmacology 2016, 102, 158-173. https://doi.org/10.1016/j.neuropharm.2015.11.004.

(15) Blum, A. P.; Lester, H. A.; Dougherty, D. A. Nicotinic Pharmacophore: The Pyridine $\mathrm{N}$ of Nicotine and Carbonyl of Acetylcholine Hydrogen Bond across a Subunit Interface to a Backbone NH. Proc Natl Acad Sci USA 2010, 107 (30), 13206-13211. https://doi.org/10.1073/pnas.1007140107.

(16) Xiu, X.; Puskar, N. L.; Shanata, J. A.; Lester, H. A.; Dougherty, D. A. Nicotine Binding to Brain Receptors Requires a Strong Cation-Pi Interaction. Nature 2009, 458 (7237), 534-537. https://doi.org/10.1038/nature07768.

(17) Van Arnam, E. B.; Dougherty, D. A. Functional Probes of Drug-Receptor Interactions Implicated by Structural Studies: Cys- 
Loop Receptors Provide a Fertile Testing Ground. J Med Chem 2014, 57 (15), 6289-6300. https://doi.org/10.1021/jm500023m.

(18) Puskar, N. L.; Xiu, X.; Lester, H. A.; Dougherty, D. A. Two Neuronal Nicotinic Acetylcholine Receptors, Alpha4beta4 and Alpha7, Show Differential Agonist Binding Modes. J Biol Chem 2011, 286 (16), 14618-14627. https://doi.org/10.1074/jbc.M110.206565.

(19) Etter, J.-F. Cytisine for Smoking Cessation: A Literature Review and a Meta-Analysis. Arch. Intern. Med. 2006, 166 (15), 15531559. https://doi.org/10.1001/archinte.166.15.1553.

(20) Etter, J.-F.; Lukas, R. J.; Benowitz, N. L.; West, R.; Dresler, C. M. Cytisine for Smoking Cessation: A Research Agenda. Drug Alcohol Depend. 2008, 92 (1-3), 3-8. https://doi.org/10.1016/j.drugalcdep.2007.06.017.

(21) Cahill, K.; Lindson-Hawley, N.; Thomas, K. H.; Fanshawe, T. R.; Lancaster, T. Nicotine Receptor Partial Agonists for Smoking Cessation. Cochrane Database Syst. Rev. 2016, No. 5, CD006103. https://doi.org/10.1002/14651858.CD006103.pub7.

(22) Walker, M. A.; Williams, G. S.; Kohl, T.; Lehnart, S. E.; Jafri, M.; Greenstein, J. L.; Lederer, W.; Winslow, R. L. Superresolution Modeling of Calcium Release in the Heart. Biophys $J$ 2014, 107 (12), 3018-3029. https://doi.org/10.1016/j.bpj.2014.11.003.

(23) West, R.; Zatonski, W.; Cedzynska, M.; Lewandowska, D.; Pazik, J.; Aveyard, P.; Stapleton, J. Placebo-Controlled Trial of Cytisine for Smoking Cessation. N. Engl. J. Med. 2011, 365 (13), 11931200. https://doi.org/10.1056/NEJMoa1102035.

(24) Canu Boido, C.; Sparatore, F. Synthesis and Preliminary Pharmacological Evaluation of Some Cytisine Derivatives. Il Farm. 1999, $54 \quad$ (7), 438-451. https://doi.org/10.1016/S0014827X(99)00049-X.

(25) Rollema, H.; Shrikhande, A.; Ward, K.; Tingley, F.; Coe, J.; O'Neill, B.; Tseng, E.; Wang, E.; Mather, R.; Hurst, R.; Williams, K.E.; de Vries, M.; Cremers, T.; Bertrand, S.; Bertrand, D. Pre-Clinical Properties of the A4 $\beta 2$ Nicotinic Acetylcholine Receptor Partial Agonists Varenicline, Cytisine and Dianicline Translate to Clinical Efficacy for Nicotine Dependence. Br. J. Pharmacol. 2010, 160 (2), 334 345. https://doi.org/10.1111/j.1476-5381.2010.00682.x

(26) Peng, C.; Stokes, C.; Mineur, Y. S.; Picciotto, M. R.; Tian, C.; Eibl, C.; Tomassoli, I.; Guendisch, D.; Papke, R. L. Differential Modulation of Brain Nicotinic Acetylcholine Receptor Function by Cytisine, Varenicline, and Two Novel Bispidine Compounds: Emergent Properties of a Hybrid Molecule. J Pharmacol Exp Ther 2013, 347 (2), 424-437. https://doi.org/10.1124/jpet.113.206904.

(27) Ivachtchenko, A. V.; Khvat, A.; Tkachenko, S. E.; Sandulenko, Y. B.; Vvedensky, V. Y. Access to Novel Substituted Diazaadamantanes via Semi-Natural Tetrahydrocytisine. Tetrahedron Lett 2004, 45 (36), 6733-6736. https://doi.org/10.1016/j.tetlet.2004.07.056.

(28) Philipova, I.; Stavrakov, G.; Vassilev, N.; Nikolova, R.; Shivachev, B.; Dimitrov, V. Cytisine as a Scaffold for Ortho-Diphenylphosphinobenzenecarboxamide Ligands for Pd-Catalyzed Asymmetric Allylic Alkylation. J Organomet Chem 2015, 778, 10-20. https://doi.org/10.1016/j.jorganchem.2014.12.001.

(29) Marcaurelle, L. A.; Johannes, C.; Yohannes, D.; Tillotson, B. P.; Mann, D. Diversity-Oriented Synthesis of a Cytisine-Inspired Pyridone Library Leading to the Discovery of Novel Inhibitors of Bcl2. Bioorg Med Chem Lett 2009, 19 (9), 2500-2503. https://doi.org/10.1016/j.bmcl.2009.03.037.

(30) Rouden, J.; Ragot, A.; Gouault, S.; Cahard, D.; Plaquevent, J.-C.; Lasne, M.-C. Regio- and Diastereoselective Functionalization of (-)-Cytisine: An Unusual N-C Acyl Migration. Tetrahedron Asymmetry 2002, 13 (12), 1299-1305. https://doi.org/10.1016/S09574166(02)00271-9.

(31) Houllier, N.; Gouault, S.; Lasne, M.-C.; Rouden, J. Regioand Diastereoselective Functionalization of (-)-Cytisine. Tetrahedron 2006, 62, 11679-11686. https://doi.org/10.1016/j.tet.2006.09.057.

(32) Dallanoce, C.; Frigerio, F.; Martelli, G.; Grazioso, G.; Matera, C.; Pomè, D. Y.; Pucci, L.; Clementi, F.; Gotti, C.; De Amici, M. Novel Tricyclic Delta(2)-Isoxazoline and 3-Oxo-2-Methyl-Isoxazolidine Derivatives: Synthesis and Binding Affinity at Neuronal Nicotinic Acetylcholine Receptor Subtypes. Bioorg. Med. Chem. 2010, 18 (12), 4498-4508. https://doi.org/10.1016/j.bmc.2010.04.065.
(33) Yohannes, D.; Hansen, C. P.; Akireddy, S. R.; Hauser, T. A.; Kiser, M. N.; Gurnon, N. J.; Day, C. S.; Bhatti, B.; Caldwell, W. S. First Total Synthesis of (+/-)-3-Hydroxy-11-Norcytisine: Structure Confirmation and Biological Characterization. Org Lett 2008, 10 (23), 5353-5356. https://doi.org/10.1021/ol802145b.

(34) Imming, P.; Klaperski, P.; Stubbs, M. T.; Seitz, G.; Gündisch, D. Syntheses and Evaluation of Halogenated Cytisine Derivatives and of Bioisosteric Thiocytisine as Potent and Selective NAChR Ligands. Eur. J. Med. Chem. 2001, 36 (4), 375-388.

(35) Marrière, E.; Rouden, J.; Tadino, V.; Lasne, M.-C. Synthesis of Analogues of (-)-Cytisine for in Vivo Studies of Nicotinic Receptors Using Positron Emission Tomography. Org. Lett. 2000, 2 (8), 1121-1124. https://doi.org/10.1021/ol005685m.

(36) Chellappan, S. K.; Xiao, Y.; Tueckmantel, W.; Kellar, K. J.; Kozikowski, A. P. Synthesis and Pharmacological Evaluation of Novel 9- and 10-Substituted Cytisine Derivatives. Nicotinic Ligands of Enhanced Subtype Selectivity. J Med Chem 2006, 49 (9), 2673-2676. https://doi.org/10.1021/jm051196m.

(37) Kozikowski, A. P.; Chellappan, S. K.; Xiao, Y.; Bajjuri, K. M.; Yuan, H.; Kellar, K. J.; Petukhov, P. A. Chemical Medicine: Novel 10-Substituted Cytisine Derivatives with Increased Selectivity for A1pha4beta2 Nicotinic Acetylcholine Receptors. ChemMedChem 2007, 2 (8), 1157-1161. https://doi.org/10.1002/cmdc.200700073.

(38) Coe, J. W.; Brooks, P. R.; Vetelino, M. G.; Wirtz, M. C.; Arnold, E. P.; Huang, J.; Sands, S. B.; Davis, T. I.; Lebel, L. A.; Fox, C. B.; Shrikhande, A.; Heym, J.H.; Schaeffer, E.; Rollema, H.; Lu, Y.; Mansbach, R.S.; Chambers, L.K.; Rovetti, C.C.; Schulz, D.W.; Tingley, F.D.; O'Neill, B. Varenicline: An Alpha4beta2 Nicotinic Receptor Partial Agonist for Smoking Cessation. J Med Chem 2005, 48 (10), 3474-3477. https://doi.org/10.1021/jm050069n.

(39) Tavares, X. D. S. da S.; Blum, A. P.; Nakamura, D. T.; Puskar, N. L.; Shanata, J. A.; Lester, H. A.; Dougherty, D. A. Variations in Binding among Several Agonists at Two Stoichiometries of the Neuronal, A4ß2 Nicotinic Receptor. J Am Chem Soc 2012, 134 (28), 11474-11480. https://doi.org/10.1021/ja3011379.

(40) Marotta, C. B.; Rreza, I.; Lester, H. A.; Dougherty, D. A. Selective Ligand Behaviors Provide New Insights into Agonist Activation of Nicotinic Acetylcholine Receptors. ACS Chem Biol 2014, 9 (5), 1153-1159. https://doi.org/10.1021/cb400937d.

(41) Durkin, P.; Magrone, P.; Matthews, S.; Dallanoce, C.; Gallagher, T. Lactam Enolate-Pyridone Addition: Synthesis of 4-Halocytisines. Synlett 2010, 2010 (18), 2789-2791. https://doi.org/10.1055/s0030-1259006.

(42) Hirschhäuser, C.; Haseler, C. A.; Gallagher, T. Core Modification of Cytisine: A Modular Synthesis. Angew Chem Int Ed Engl 2011, 50 (22), 5162-5165. https://doi.org/10.1002/anie.201100441.

(43) Campello, H.; Villar, S. G.; Honraedt, A.; Minguez, T.; Oliveira, S. A.; Ranaghan, K. E.; Shoemark, D. K.; Bermudez, I.; Gotti, C.; Sessions, R. B.; Mulholland, A.J.; Wonnacott, S.; Gallagher, T. Unlocking Nicotinic Selectivity via Direct C-H Functionalization of (-)Cytisine. Chem 2018, 4 (7), 1710-1725. https://doi.org/10.1016/j.chempr.2018.05.007.

(44) Post, M. R.; Tender, G. S.; Lester, H. A.; Dougherty, D. A. Secondary Ammonium Agonists Make Dual Cation- $\pi$ Interactions in A4ß2 Nicotinic Receptors. eNeuro 2017, 4 (2), ENEURO.003217.2017. https://doi.org/10.1523/ENEURO.0032-17.2017.

(45) Duffy, N. H. Studies of the Serotonin Type 3A Receptor and the Chemical Preparation of TRNA. phd, California Institute of Technology, 2014. https://doi.org/Duffy, Noah Hanville (2014) Studies of the Serotonin Type 3A Receptor and the Chemical Preparation of tRNA. Dissertation (Ph.D.), California Institute of Technology. doi:10.7907/X1YA-DM13. http://resolver.caltech.edu/CaltechTHESIS:05062014-151417635 <http://resolver.caltech.edu/CaltechTHESIS:05062014-151417635>

(46) Rucktooa, P.; Haseler, C. A.; van Elk, R.; Smit, A. B.; Gallagher, T.; Sixma, T. K. Structural Characterization of Binding Mode of Smoking Cessation Drugs to Nicotinic Acetylcholine Receptors through Study of Ligand Complexes with Acetylcholine-Binding Protein. J Biol Chem 2012, 287 (28), 23283-23293. https://doi.org/10.1074/jbc.M112.360347. 
(47) Dougherty, D. A. Cys-Loop Neuroreceptors: Structure to the Rescue? Chem Rev 2008, 108 (5), 1642-1653. https://doi.org/10.1021/cr078207z.

(48) Cashin, A. L.; Torrice, M. M.; A, M., Kathryn; Lester, H. A.; Dougherty, D. A. Chemical-Scale Studies on the Role of a Conserved Aspartate in Preorganizing the Agonist Binding Site of the Nicotinic Acetylcholine Receptor. Biochemistry 2007, 46 (3), 630-639. https://doi.org/10.1021/bi061638b.

(49) Horovitz, A. Double-Mutant Cycles: A Powerful Tool for Analyzing Protein Structure and Function. Fold Des 1996, 1 (6), R121R126. https://doi.org/10.1016/S1359-0278(96)00056-9.

(50) Kao, C.; Zheng, M.; Rüdisser, S. A Simple and Efficient Method to Reduce Nontemplated Nucleotide Addition at the 3 Terminus of RNAs Transcribed by T7 RNA Polymerase. RNA N. Y. N 1999, $5(9), 1268-1272$.
(51) Nowak, M.; Gallivan, J.; Silverman, S.; Labarca, C.; Dougherty, D.; Lester, H. In Vivo Incorporation of Unnatural Amino Acids into Ion Channels in Xenopus Oocyte Expression System. Methods Enzymol. 1998, 293, 529.

(52) England, P. M.; Lester, H. A.; Dougherty, D. A. Incorporation of Esters into Proteins: Improved Synthesis of Hydroxyacyl TRNAs. Tetrahedron Lett 1999, 40 (34), 6189-6192. https://doi.org/10.1016/s0040-4039(99)01300-3. 


\section{For Table of Contents Only}

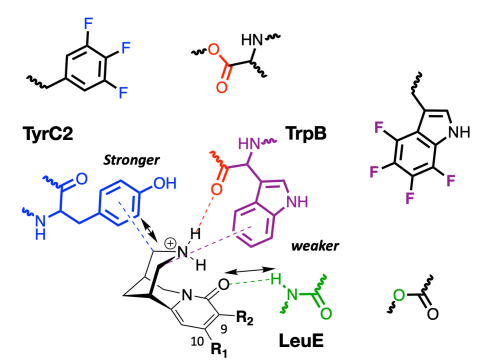

$\begin{array}{ll}\mathrm{R}_{1}= & \mathrm{F} / \mathrm{Me} / \mathrm{OMe} / \mathrm{CF}_{3} / \mathrm{Et} / \mathrm{NH}_{2} / \mathrm{NHCH}_{3} \\ \mathrm{R}_{2}=\mathrm{H} / \mathrm{Br}\end{array}$ 